\title{
Relationship among uterine involution, ovarian activity, blood metabolites and subsequent reproductive performance in Egyptian buffaloes
}

\author{
Hassan A. Hussein ${ }^{1^{*}}$, Waleed Senosy ${ }^{1}$, Mahmoud R. Abdellah ${ }^{2}$ \\ ${ }^{1}$ Theriogenology Department, Faculty of Veterinary Medicine, Assiut University, Assiut, Egypt; \\ *Corresponding Author: hassansabour69@yahoo.com \\ ${ }^{2}$ Clinical Laboratory Diagnosis, Department of Animal Medicine, Faculty of Veterinary Medicine, Assiut University, Assiut, Egypt
}

Received 19 October 2012; revised 22 November 2012; accepted 28 November 2012

\begin{abstract}
The aim of the study to monitor post partal uterine involution, ovarian activity and biochemical parameters and it is relation to the subsequent fertility. A total sixty normal calving pluriparous buffaloes were examined between $14^{\text {th }}$ and $75^{\text {th }}$ day post partum (p.p.) rectaly, ultrasonically and blood sampling were collected on weekly sessions. There were differences $(P<0.01)$ between pregnant (PREG) and non-pregnant (NPREG) groups in Body condition score (BCS) and body weights. There was a difference between previous gravid uterine horn (PGUH) and non-gravid uterine horn (NPGUH) diameter in PREG and NPREG groups at 28th day p.p. The calving to first service interval in the PREG group was shorter $(P=0.03)$ than that of NPREG one. The number of buffaloes with dominant follicles (DF $\geq 8 \mathrm{~mm}$ diameter) in ipsilateral and contralateral ovary to the PGUH in PREG group was higher ( $P$ $<0.01$ ) than in NPREG. The calving to first service interval in the PREG group having DF in the ovary ipsilateral to the PGUH $(n=16)$ was shorter $(P<0.01)$ than those buffaloes having no DF $(n=18)$. The number of service per conception and days open in the PREG buffaloes which had no DF in the ovary ipsilateral to the PGUH were higher and longer $(P<0.01)$ than that which had DF group. The values of glucose and triglyceride were higher $(P=0.057)$ in PREG than NPREG group. In conclusion, postpartum ovarian activity has positive effect on the uterine involution and postpartum profile of some metabolities may be a good predictor of fertility status of buffaloes.
\end{abstract}

Keywords: Reproductive Performance; Ovarian Activity; Uterine Involution; Metabolic Profile; Egyptian Buffaloes

\section{INTRODUCTION}

The main priorities of the Egyptian agriculture are milk and meat production. Buffaloes are characterized by good milk production and quality. A big problem is the establishment of a new pregnancy during 90 days postpartum (PP) in buffaloes [1]. After calving, if the nutrition level was low and the milk production was high this will leads to a situation called negative energy balance (NEB). That in turn affects negatively and dramatically the post partum ovarian resumption [2]. However, the interaction between the hypothalamic-pituitary-ovarian axis and the metabolic status of the animal is very complex and controversial [3]. Decreasing in the dry matter intake during peripartum period and high energy requirement for milk production leads to NEB during pp and accumulation of triglceride (TG) in the liver [4]. The presence of NEB, which is to a certain degree assumed to be physiological, evokes a mobilization of non-esterified fatty acids (NEFA) and an accumulation of TG in the liver. Some authors confirmed a negative relationship between high concentrations of TG in the liver and subsequent fertility [5], but other studies revealed no significant or unequivocal relationship [6]. It was suggested that the negative relationship between liver TG and fertility is caused by higher milk production or attempts of the farmer to breed cows earlier postpartum [2]. Moreover, there are reports that described negative effects of the severity and duration of NEB on fertility. For example, days to NEB nadir is reported to be correlated to days to first ovulation $[7,8]$ and luteal function [9]. Despite the well-known effect of energy balance on reproductive 
efficiency in high yielding dairy cows, the effect on reproductive performance in medium-low yielding dairy buffaloes is still unknown. No sufficient scientific investigations concerning the uterine involution, resumption of ovarian activity and metabolic status, has been done in Egyptian buffaloes. The aim of the study to monitor post partal uterine involution, ovarian activity and biochemical parameters and its relation to the subsequent fertility in Egyptian buffaloes.

\section{MATERIALS AND METHODS}

\subsection{Animals and Management}

A total of sixty normal calving pluriparous buffaloes with live body weight ranged between 402 and $612 \mathrm{~kg}$ $(507.14 \pm 18.90 \mathrm{~kg}$; mean $\pm \mathrm{SEM})$ and body condition score (BCS) of $2.9 \pm 0.15$ were included in this study. The animals belonged to buffalo farm in El-Badary city, Assiut province, Egypt (latitude: 8.2 meters, 25.4 centimetres, $58 \mathrm{~N}$; longitude 10.1 meters, 25.4 centimetres, $58 \mathrm{E}$; altitude $37 \mathrm{~m}$ ), kept in free-stall barns and fed $a d$ libitum according to NRC [10]. The total mixed ration (TMR) included mainly alfalfa, corn silage, beet pulp, cotton seed, soyabean, corn and barley. All animals were apparently clinically healthy and free from external and internal parasites. The cows were machine-milked twice daily at $5.00 \mathrm{am}$ and at $6 \mathrm{pm}$. The mean 305-day milk yield of the cows in the preceding lactation was 2592.80 $\mathrm{kg}$ the animals were lived under the same management and prevalent environmental conditions between October 2009 and February 2010.

\subsection{Experimental Design}

All buffaloes were examined till the $75^{\text {th }}$ day postpartum (p.p.) starting from $14^{\text {th }}$ day p.p. on a weekly basis. During the examination, cows were examined by vaginoscope and transrectal ultrasonography (US) after normal parturition.

\subsection{Body Condition Scoring and Animal Weight}

In all animals Body Condition Score (BCS) was conducted at each examination based on a scale from 1 (emaciated) to 5 (very fat) [11]. The animals were weighted each time and recorded till further analysis.

\subsection{Gynaecological and Transrectal Ultrasonographic Examinations}

Transrectal palpation was carried out to assess the position and degree of uterine involution. An attempt to monitor uterine involution was done by measuring the weekly variation of the transverse diameter of the uterine horns in ultrasonographic image. Since it was difficult to achieve consistent measurements, uterine involution was considered complete when the uterus was reduced in size, easily retractable, had normal tonicity and was completely located in the pelvic cavity. Reproductive tract measurements included uterine horn size at the base of the horn, ovarian status. The uterus was considered involuted when the difference between pregnant and non-pregnant horns became $<10 \mathrm{~mm}$, while non-involuted uterus when the difference between both horns was $\geq 10 \mathrm{~mm}$ [12]. The cervical diameter (CD), previous gravid uterine horn (PGUH) and non-gravid uterine horn (NPGUH) diameters were determined transrectally. The PGUH was differentiated from NPGUH where it was longer and of greater diameter than the NPGUH at the first examination $\left(14^{\text {th }}\right.$ day) $[12,13]$. Ultrasonographic evaluation was performed using a $6 / 8 \mathrm{MHz}$ rectal linear array transducer connected to B-mode ultrasound scanner (100 LC, Pie Medical, Masstricht, The Netherlands). Data obtained by ultrasonography included: diameter of the uterine horns $(\mathrm{mm})$, number and size of follicles ( $\geq 5 \mathrm{~mm}$ ), presence of luteal tissue (yes/no), and presence of fluid in the uterine horns (yes/no). The ultrasonographic equipment was supplied with image freeze and electronic calliper functions for taking measurements. Follicles were defined as nonechogenic rounded structures with a clear demarcation between the follicular wall and antrum. A corpus luteum (CL) was defined as a grainy echogenic structure that had a well-defined border with the less echogenic ovarian stroma, and in some corpora lutea, there was a nonechodense lacuna [14]. The maximum diameter of each structure was measured using the electronic calliper. The number of small follicle ( $\geq 5 \mathrm{~mm}$ diameter), dominant follicle (DF, $\geq 8 \mathrm{~mm}$ diameter) and $\mathrm{CL}$ in both ovaries (ipsilateral and contralateral) to the previous gravid uterine horn was recorded.

\subsection{Blood Sampling, Biochemical and Steroids Assays}

Blood samples were collected from the jugular vein into heparinized vacutainer tubes (Becton-Dickinson, Franklin Lakes, NJ) at $14-28,29-36,37$ - 44, 45 - 60 and 61 - 75 days postpartum for determination of plasma concentrations of Progesterone (P4), Estrogens (E2), triglyceride, cholesterol, high density lipoprotein cholesterol (HDL-C), low density lipoprotein cholesterol (LDLC), very low density lipoprotein cholesterol (VLDL-C) and glucose. Progesterone was analyzed to assure the presence of luteal tissue which indicated resumption of reproductive cyclicity. Plasma estrogen (E2) and progesterone (P4) concentrations were determined using ELISA kits (Bio Check, Foster City, CA 94404, USA) using the micro-well method. The kit had a sensitivity of $10 \mathrm{pg} / \mathrm{ml}$ 
with the inter- and intra-run precision coefficient of variations of $6.4 \%$ and $4.1 \%$, respectively for estrogen, while for progesterone, the sensitivity of $0.0625 \mathrm{ng} / \mathrm{ml}$ with the inter- and intra-run precision coefficient of variations of $4.5 \%$ and $2.6 \%$. Glucose (Glu, gm/l), total cholesterol (C, mg/l) triglyceride ( $\mathrm{TG}, \mathrm{mg} / \mathrm{l})$ and highdensity lipoprotein cholesterol (HDL-C) were determined colorometrically using commercial test kits supplied and by Digital Ultraviolet Spectrophotometer (Digital Ultraviolet Spectrophotometer, CE 292, series 2, Cecil instruments, Cambridge England, Series No. 52.232). Lowdensity lipoprotein cholesterol (LDL-C) was calculated according to Friedewald et al. [15].

\subsection{Animal Breeding and Pregnancy Diagnosis}

Animals were bred after a voluntary waiting period of 70 - 85 days pp. They were bred after spontaneous normal estrus by natural mating using a good fertile buffalo bull. Pregnancy was diagnosed using transrectal ultrasonographic examination at 60 and 90 days post-service. Pregnancy status at 90 days was used for the analysis. Based on 90 days pregnancy diagnosis within 250 days $\mathrm{pp}$, overall conception rate (OACR), interval from calving to first service (DFS), number of service per conception, and days open (DO) were calculated, and the animals retrospectively were allocated into pregnant group (PREG, animals that became pregnant at 90 days post estrus) and non-pregnant group (NPREG, animals that failed to become pregnant within 250 days $\mathrm{pp}$ ).

\subsection{Statistical Analysis}

The principal points of the study were predomination ovarian structures, uterine involution and blood metabolites as energy indicators in all animals starting from $14^{\text {th }}$ to $75^{\text {th }}$ day p.p. and the interaction of these factors on the reproductive performance. The general linear models ANOVA for repeated measures [16] was used for determining the main effects of each group and days, and their interaction. If a significant effect of time or a significant interaction was determined, a Fisher's least significant differences (LSD) test was used as a post hoc analysis to locate mean differences among groups within days and among days within groups. Using Chi-square, outcomes measured to assess reproductive performance as overall conception rate $(\%)$ and Interval from calving to first estrus were compared. The diameter of previous gravid uterine horn (PGUH) and the uterine horn contralateral to it (NPGUH) and cervical diameters as well as number of small and dominant follicles and the proportion of buffaloes with follicles $\geq 8 \mathrm{~mm}$ were compared in the two groups (pregnant and non-pregnant) using t-test. Level of significance was set at $\mathrm{P}<0.05$.

\section{RESULTS}

\subsection{Conception Rate}

In the present work, over all conception rate (OACR) was 34 animals of 60 (56.66\%), while 26 animals (43.33\%) were diagnosed as non pregnant.

\subsection{Animal Weight and BCS}

Body weight and BCS presented in Table 1. There were significant differences between pregnant and non-pregnant groups in overall means of BCS and body weights during p.p. $(\mathrm{P}<0.01)$. The differences in BCS and body weight at the periods of examinations between the two groups were not significant up to the $24^{\text {th }}$ day p.p., thereafter there were significant differences up to $75^{\text {th }}$ day p.p. (Figure 1).

\subsection{Uterine Condition, Ovarian Findings and First p.p. Reproductive Performance}

The data of uterine and ovarian findings were showed in Tables 1-3. There was a significant difference between PGUH and NPGUH diameter in pregnant, non-pregnant groups at $28^{\text {th }}$ day postpartum. There were no significant

Table 1. The overall mean of post partum weight, BCS and uterine condition in buffaloes.

\begin{tabular}{lccc}
\hline \multicolumn{1}{c}{ Parameters } & Buffaloes became pregnant & Buffaloes became non-pregnant & Significance \\
\hline Number of animals & $34 / 60(56.66 \%)$ & $26 / 60(43.33 \%)$ & 0.36 \\
BCS & $3.25 \pm 0.08$ & $2.65 \pm 0.10$ & 0.01 \\
Body weight (kg) & $551.2 \pm 26.58$ & $416.4 \pm 21.32$ & $3.03 \pm 0.23$ \\
Cervical diameter (cm) & $3.17 \pm 0.21$ & $6.40 \pm 1.01$ & 0.01 \\
Diameter of PGUH at 28 days (cm) & $3.81 \pm 0.91$ & $10 / 26(38.46 \%)$ & 0.01 \\
Intrauterine fluid & $13 / 34(38.23 \%)$ & $93.20 \pm 9.81$ & 0.03 \\
Interval from calving to first estrus (days) & $65.71 \pm 11.31$ & & \\
\hline
\end{tabular}




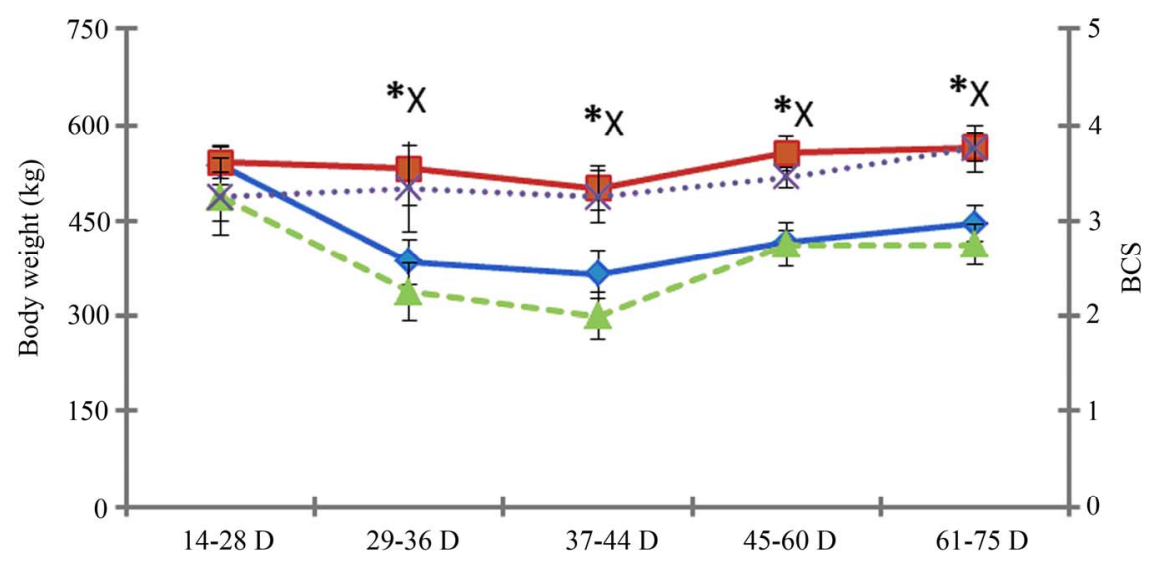

Days post partum

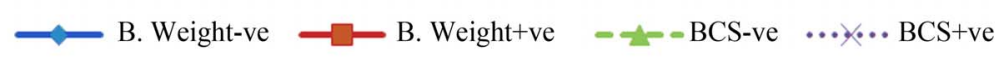

Figure 1. Body weight and BCS during p.p. period in pregnant $(\mathrm{n}=34)$ and non pregnant $(\mathrm{n}=26)$ buffaloes (Mean \pm SEM). ${ }^{*}$ Significant difference between the body weight of the pregnant and non pregnant buffaloes $(\mathrm{P}<0.01)$; ${ }^{\mathrm{x}}$ Significant difference between the BCS of the pregnant and non pregnant buffaloes $(\mathrm{P}<0.01)$.

Table 2. The number of follicles $\geq 5 \mathrm{~mm}$ diameter in the ovary ipsilateral or contralateral to the PGUH at 2 time periods post-partum.

\begin{tabular}{|c|c|c|c|c|c|c|}
\hline \multirow{2}{*}{ Calving to examination period (days) } & \multicolumn{2}{|c|}{ Pregnant buffaloes $(\mathrm{n}=34)$} & \multirow{2}{*}{$P$ value } & \multicolumn{2}{|c|}{ Non-pregnant buffaloes $(\mathrm{n}=26)$} & \multirow{2}{*}{ P value } \\
\hline & Ipsilateral ovary & Contralateral ovary & & Ipsilateral ovary & Contralateral ovary & \\
\hline No. of follicles $\geq 5 \mathrm{~mm}$ at 14 - 21 days p.p. & $0.91 \pm 0.20$ & $2.83 \pm 0.31$ & 0.00 & $0.82 \pm 0.11$ & $2.61 \pm 0.21$ & 0.00 \\
\hline No. of follicles $\geq 5 \mathrm{~mm}$ at 22 - 28 days p.p. & $1.22 \pm 0.40$ & $2.53 \pm 0.32$ & 0.01 & $1.40 \pm 0.51$ & $2.72 \pm 0.40$ & 0.01 \\
\hline Total & $1.51 \pm 0.30$ & $2.61 \pm 0.20$ & 0.01 & $1.51 \pm 0.10$ & $3.01 \pm 0.43$ & 0.01 \\
\hline
\end{tabular}

Table 3. The percent of animals possessing follicles $\geq 8 \mathrm{~mm}$ diameter (DF) and CL in the ovary ipsilateral or contralateral to the PGUH between 14 - 28 days postpartum.

\begin{tabular}{|c|c|c|c|c|}
\hline \multirow{2}{*}{ Site of location DF or CL } & \multicolumn{2}{|c|}{ Pregnant buffaloes $(\mathrm{n}=34)$} & \multicolumn{2}{|c|}{ Non-pregnant buffaloes $(\mathrm{n}=26)$} \\
\hline & DF & CL & DF & CL \\
\hline No. of animals having $\mathrm{DF} / \mathrm{CL}$ in ipsilateral ovary to PGUH & $\begin{array}{c}16 / 34^{\mathrm{a}} \\
(47.05 \%)\end{array}$ & $\begin{array}{c}6 / 34^{\mathrm{c}} \\
(17.64 \%)\end{array}$ & $\begin{array}{c}4 / 26^{\mathrm{b}} \\
(15.38 \%)\end{array}$ & $\begin{array}{c}17 / 26^{\mathrm{d}} \\
(65.38 \%)\end{array}$ \\
\hline No. of animals having DF/CL in contralateral ovary to PGUH & $\begin{array}{c}26 / 34^{\mathrm{a}} \\
(76.47 \%)\end{array}$ & $\begin{array}{c}12 / 34^{\mathrm{c}} \\
(35.29 \%)\end{array}$ & $\begin{array}{c}8 / 26^{\mathrm{b}} \\
(30.76 \%)\end{array}$ & $\begin{array}{c}5 / 26^{\mathrm{d}} \\
(19.23 \%)\end{array}$ \\
\hline No. of animals having DF/CL in both ovaries & $\begin{array}{c}8 / 34 \\
(23.52 \%)\end{array}$ & $\begin{array}{c}2 / 34 \\
(5.88 \%)\end{array}$ & $\begin{array}{c}3 / 26 \\
(11.53 \%)\end{array}$ & $\begin{array}{c}1 / 26 \\
(3.84 \%)\end{array}$ \\
\hline
\end{tabular}

Means with different superscript in the same row significant differ (a:b, c:d, $\mathrm{P}<0.01$ ).

differences in cervical diameter and the number of animals showing intrauterine fluid up to Day 28 p.p. between the two groups. The Interval from calving to first estrus in the pregnant group was shorter than that in non-pregnant group (Table 1).

Follicles ( $\geq 5 \mathrm{~mm}$ diameter) were observed in both ovaries ipsilateral and contralateral to the PGUH. There was no significant difference in number of those follicles between pregnant and non-pregnant animals. The num- ber of the same follicles in the ovary ipsilateral to the PGUH was fewer $(\mathrm{P}<0.01)$ than that in the ovary contralateral to the PGUH between 14 - 28 days p.p. (Table 2).

The proportion of buffaloes with follicles $\geq 8 \mathrm{~mm}$ diameter in ipsilateral and contralateral ovary to the PGUH in pregnant animals was higher $(\mathrm{P}<0.01)$ than that in the non-pregnant buffaloes. The number of buffaloes having $\mathrm{CL}$ in ipsilateral ovary to the PGUH in non-pregnant group was higher $(\mathrm{P}<0.01)$ than that in the pregnant 
buffaloes. The number of corpora lutea in contralateral ovary to the PGUH in pregnant animals was higher $(\mathrm{P}<$ 0.01 ) than that in non-pregnant buffaloes (Table 3). The Interval from calving to first service in the pregnant buffaloes which had DF in the ovary ipsilateral to the PGUH $(\mathrm{n}=16)$ was shorter $(\mathrm{P}<0.01)$ than that having no dominant follicles $(\mathrm{n}=18)$. The number of service per conception and days open in the pregnant buffaloes without $\mathrm{DF}$ in the ovary ipsilateral to the PGUH were higher and longer $(\mathrm{P}<0.01)$ than in buffaloes group possessing DF (Table 4).

\subsection{Plasma P4 and Estrogens Concentrations}

The overall mean of P4 and E2 concentration during p.p. in pregnant and non-pregnant buffaloes showed in Table 5. There were significant differences between the two groups in overall mean of P4 and E2 concentrations. Significant differences in the P4 concentration were re- corded between groups at 14 - 45 days p.p. Estrogen concentration showed significant differences between pregnant and non-pregnant at $29-45$ days p.p. After $45^{\text {th }}$ day, the differences in both P4 and E2 in the two groups were not clear (Figure 2).

\subsection{Blood Metabolic and Biochemical Parameters}

Overall mean of Plasma Glucose, cholesterol, Triglyceride, lipoprotein cholesterol and steroid hormone in pregnant and non-pregnant buffaloes during the experiment was presented in Table 5. The concentrations of glucose and triglyceride were higher $(\mathrm{P}=0.057)$ in pregnant than non-pregnant group. LDL-C and VLDL-C concentrations were higher $(\mathrm{P}<0.01)$ in non-pregnant group than pregnant buffaloes. There were no significant differences between pregnant and non-pregnant buffaloes in overall mean concentrations of cholesterol and HDL-C.

The glucose level was higher $(\mathrm{P}<0.05)$ in pregnant

Table 4. The postpartum reproductive performance in pregnant buffaloes with or without dominant follicles in the ovary ipsilateral to the PGUH between 14 - 28 days.

\begin{tabular}{lrr}
\hline \multicolumn{1}{c}{ Parameter } & \multicolumn{2}{c}{ Pregnant buffaloes (n=34) } \\
\cline { 2 - 3 } & Buffaloes with DF/PGUH ${ }^{*}(\mathrm{n}=16)$ & Buffaloes without DF/PGUH (n $=18)$ \\
\hline Calving to first p.p. estrus interval (days) & $51.30 \pm 5.40$ & $79.60 \pm 7.60$ \\
Number of service per conception & $1.85 \pm 0.21$ & $2.40 \pm 0.09$ \\
Days open (day) & $81.90 \pm 3.10$ & 0.01 \\
\hline
\end{tabular}

${ }^{*} \mathrm{DF} / \mathrm{PGUH}$, dominant follicle in the ovary ipsilateral to previous gravid uterine horn.

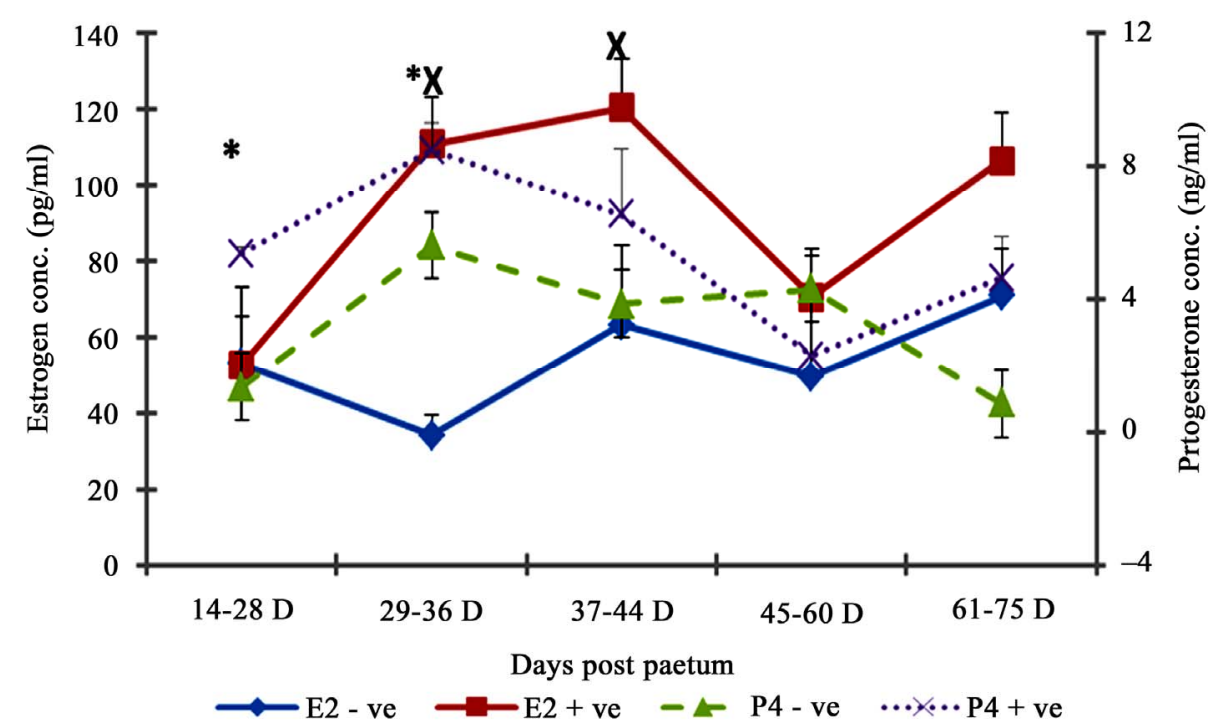

Figure 2. Plasma Estradiol-17 $\beta$ (E2) and Progesterone (P4) concentration during p.p. period in pregnant $(\mathrm{n}=34)$ and non pregnant $(\mathrm{n}=26)$ buffalo cows $($ Mean $\pm \mathrm{SEM}) .{ }^{*}$ Significant difference between the body weight of the pregnant and non pregnant buffaloes $(\mathrm{P}<0.01)$; ${ }^{\mathrm{x}}$ Significant difference between the BCS of the pregnant and non pregnant buffaloes $(\mathrm{P}<0.01)$. 
buffaloes than non-pregnant buffaloes between $14^{\text {th }}$ and $44^{\text {th }}$ days p.p., then there was no significant difference (Figure 3). In pregnant group, the level of triglyceride was higher $(\mathrm{P}<0.001)$ than non-pregnant one between $14^{\text {th }}$ and $36^{\text {th }}$ day p.p. and the highest concentration was recorded between $45^{\text {th }}$ and $60^{\text {th }}$ day (Figure 3).

The highest level of cholesterol was recorded in pregnant group between $14^{\text {th }}$ and $45^{\text {th }}$ day p.p. and the difference between pregnant and non-pregnant buffaloes was not significant. There were no significant differences in HDL-C concentrations (Figure 4).

The LDL-C level was higher $(\mathrm{P}<0.001)$ in pregnant buffaloes than non-pregnant group between $29^{\text {th }}$ and $75^{\text {th }}$ days p.p. In non-pregnant group, the level of VLDL-C was higher $(\mathrm{P}<0.01)$ between $14^{\text {th }}$ and $44^{\text {h }}$ day p.p., while was higher $(\mathrm{P}<0.01)$ in pregnant group between $45^{\text {th }}$ and $60^{\text {th }}$ day p.p. (Figure 5).

\section{DISCUSSION}

The objective of the current work was to uterine involution or resumption of estrous activity is likely to prolong the calving interval and reduce the lifetime reproductive and productive efficiency [1]. There were significant differences between pregnant and non-pregnant group in overall means of BCS and body weights during the experiment period p.p. The reported findings here are consistent with other studies, in cattle [17-19]. These results indicated that non-pregnant group suffered from NEB more than the pregnant one therefore, the loss in body weight and marked decrease in BCS between the third and tenth week p.p. associated with decrease in the

Table 5. Overall mean of biochemical parameters in pregnant and no pregnant buffaloes (Mean \pm SEM).

\begin{tabular}{cccc}
\hline Parameters & Buffaloes became pregnant & Buffaloes became non-pregnant & Significance \\
\hline Glucose (g/L) & $61.15 \pm 3.70$ & $41.54 \pm 3.90$ & 0.057 \\
Cholesterol (mg/L) & $94.02 \pm 2.09$ & $110.76 \pm 2.31$ & 0.68 \\
Triglyceride (mg/L) & $97.64 \pm 6.50$ & $68.49 \pm 8.40$ & 0.06 \\
HDL-C (mg/L) & $23.94 \pm 3.50$ & $18.35 \pm 3.10$ & 0.75 \\
LDL-C (mg/L) & $32.01 \pm 2.06$ & $53.1 \pm 4.32$ & 0.01 \\
VLDL-C (mg/L) & $7.39 \pm 0.95$ & $23.11 \pm 5.23$ & 0.05 \\
Estrogen (pg/ml) & $92.4 \pm 12.14$ & $48.8 \pm 15.39$ & 0.03 \\
Progesterone (ng/ml) & $5.47 \pm 0.17$ & $3.18 \pm 5.21$ & 0.04 \\
\hline
\end{tabular}

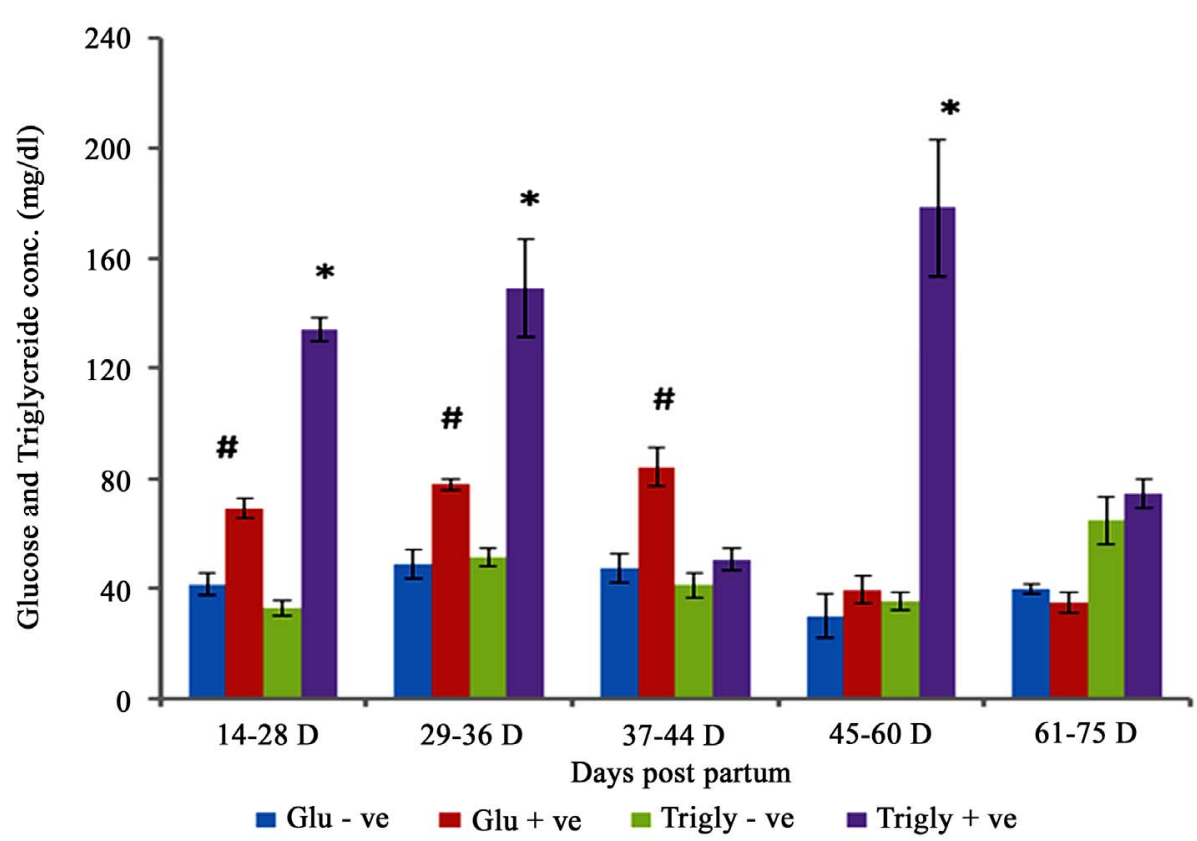

Figure 3. Plasma glucose and Triglyceride concentrations during post partum period in pregnant $(\mathrm{n}=34)$ and non pregnant $(\mathrm{n}=26)$ buffalo cows (Mean \pm SEM, \#; $\mathrm{P}<0.05$ and *; $\mathrm{P}<0.001)$. 


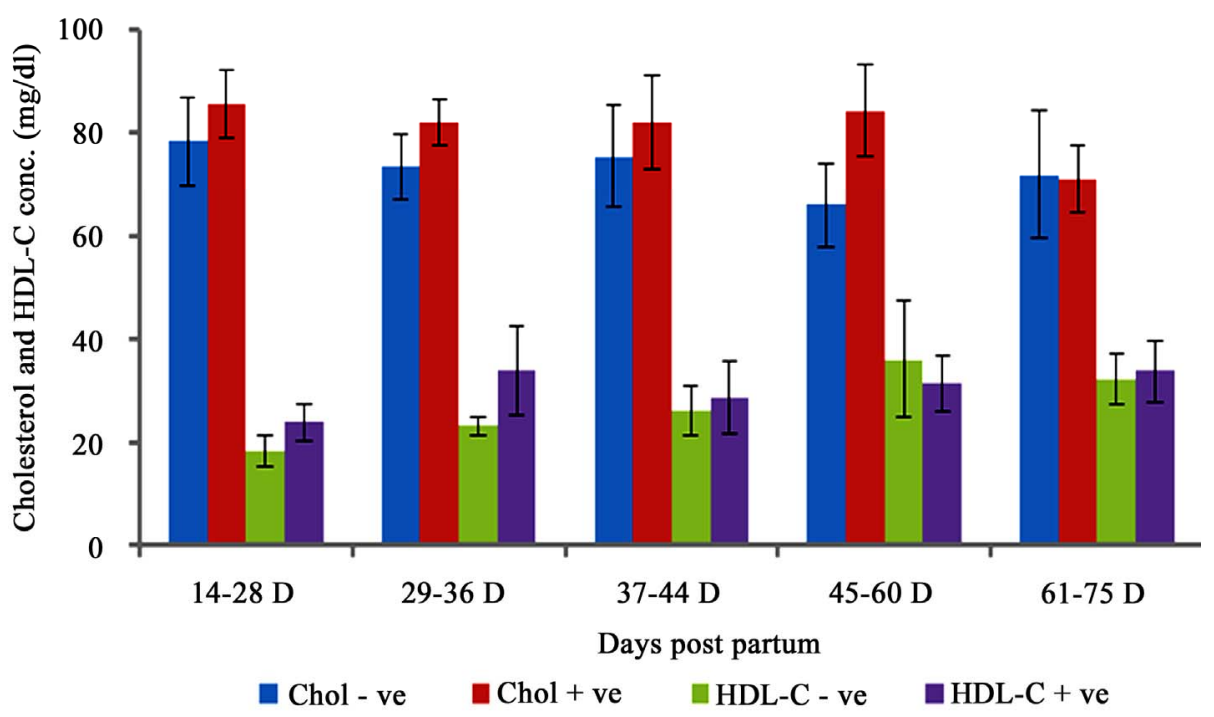

Figure 4. Plasma cholesterol and high density lipoprotein cholesterol (HDL-C) concentrations during post partum period in pregnant $(\mathrm{n}=34)$ and non pregnant $(\mathrm{n}=26)$ buffalo cows (Mean \pm SEM).

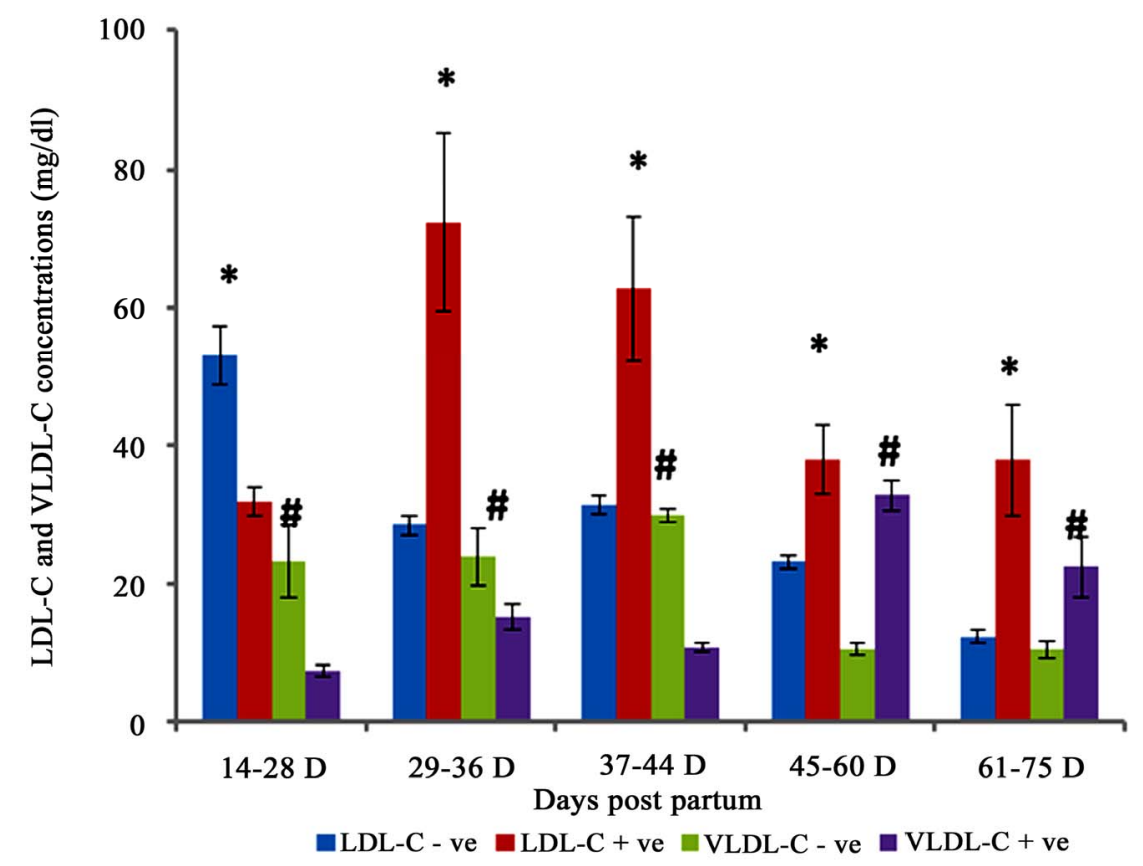

Figure 5. Plasma low density lipoprotein cholesterol (LDL-C) and very low density lipoprotein concentrations during post partum period in pregnant $(\mathrm{n}=34)$ and non pregnant $(\mathrm{n}=26)$ buffalo cows (Mean \pm SEM, *; $\mathrm{P}<0.001$, \#; $\mathrm{P}<0.01$ ).

conception rate. Earlier reports coincide with ours that body weight (BW) variation during postpartum period has an important role on reproductive performance; a more pronounced loss of BW was observed in the cows that did not resume ovarian activity compared to the cows with ovarian activity resumption within seven weeks postpartum, but the statistical analysis did not evidence differences $[18,19]$. It should be considered that in this trial, the most pronounced mean body weight loss
(-6.46\%) was less than values reported by Heinonen et al. [20] who observed lower reproductive performance in cows that lost more than $10 \%$ of BW postcalving compared with cows that lost less than $10 \%$.

No significant differences were detected in the whole period of observation in the amount of milk production. These results are consistent with other studies that found no relationship between milk production and reproduction $[21,22]$. However, most of the recent studies have 
found a negative relationship between milk production and several fertility traits [23-27]. On the contrary, Buckley et al. [18], observed a positive association between milk yield variables and reproductive efficiency.

In the current work, the number of follicles $\geq 5 \mathrm{~mm}$ diameter in the ovary ipsilateral to the PGUH was fewer than that in the ovary contralateral to the PGUH between $14-28$ days p.p. in both pregnant and non-pregnant buffaloes. In dairy cattle similar results was recorded during first 4 weeks p.p. $[28,29]$. Follicular activity started 6 days earlier in the ovaries contralateral to the gravid horn (21 days) than in the ipsilateral (27 days) ovaries [30] and was higher in the same ovaries during the first 35 postpartum days [31]. The explanation of this observation may be due to influence of the follicle on the uterine endometrium and/or myometrium. One hypothesis is that estradiol synthesized by a follicle $\geq 10 \mathrm{~mm}$ diameter has a beneficial local effect on the uterine function [28]. Plasma estradiol concentrations are greater within the uteroovarian vein draining the ovary containing the ovulatory follicle [32]. Similarly, the correlation between the uterine involution and estradiol level was observed in this work and further study should be done for better documentation this point. The findings in the present study showed that the presence of dominant follicles $\geq 10 \mathrm{~mm}$ diameter in the ovary ipsilateral to the PGUH between $14^{\text {th }}$ and $28^{\text {th }}$ Day postpartum is associated with shorter calving to conception interval and fewer number of services per conception. Our results agree with that recorded in cattle $[28,29,33]$. There was no significant difference in cervical diameter between the two groups at $28^{\text {th }}$ day p.p. The cervical involution completed earlier than uterine involution in both groups and the differences were not significant, similar results were recorded, where the cervix was completed by $24-39$ days postpartum [34-37].

It was reported that the cows which had an initial ovulation before, rather than after 41 days postpartum had shorter calving to conception intervals [38]. Similarly, Darwash et al. [39] reported a significant reduction in calving to conception interval accompanied with shorter intervals to the first post-partum increase in milk progesterone concentration, while Smith and Wallace [40] recorded the reverse. The current study showed that the proportion of buffaloes with ovarian activity as defined by ultrasonography for presence of CL and/or follicles $\geq$ $8 \mathrm{~mm}$ diameter, had a shorter calving to conception interval and became pregnant. It was observed also that during the first 6 weeks p.p., the level of both E2 and P4 was higher in pregnant buffaloes than that in non-pregnant group. The difference may be due to the number of animals having DF on both ipsilateral and contralateral ovary and CL on contralateral ovary to the PGUH. The number of $\mathrm{CL}$ on ipsilateral ovary to the PGUH was greater in non-pregnant than in pregnant group, this may be due to $C L$ of previous pregnancy retained longer in non-pregnant group. Similar results were reported in buffaloes [30] and in dairy cows [29].

Many factors affecting the initiation of follicular activity during p.p. period in buffaloes were studied; suckling [41,42], level of milk production [31] and prepartum nutrition [42]. It was recorded that suckling; milk production and prepartum nutrition did not influence the interval to initiation of follicular activity $[31,41,43]$. However, the relationship between milk production, nutrition and reproductive performance couldn't record clearly because there were no differences in the milk quantity and nutrition between the tested groups.

Earlier studies reported variable length of days open as 40 to 228 days. In non-suckled buffaloes the interval from calving to conception was reported as 126 days in Murrah [44], 168 days in Nili-Ravi [45] and 104 days in Surti breed [46]. These greatly varying intervals reported by different workers could be due to breed, nutritional status, management, soil type, weather condition and even postpartum breeding policies adopted in different areas of the country. In present work, the Interval from calving to first service in the pregnant group was shorter than that in non-pregnant group, due to earlier ovarian resumption in the pregnant than in non-pregnant group. The pregnant cows with high genetic merits showed higher days open and services per conception, even though with an earlier recovery of cyclicity. Furthermore, non pregnant with high genetic merits group, with similar energy deficiency, showed more subclinical health problems [47]. Our results were in agreement with that reported in surti buffaloes where the occurrence of first postpartum oestrus, service period and calving interval were significantly shorter/lesser in fertile group of buffaloes than the infertile one [48].

The levels of glucose fluctuated significantly during different weeks postpartum and the difference between pregnant and non-pregnant buffaloes was significant. It could be due to a high degree of negative energy balance that may affect the subsequent fertility. Similar results were reported in cows [47] but there were no differences between fertile and infertile buffaloes [48].

It is well established that LDL-cholesterol (LDL-C) is one of the most important parameters for estimating hypercholesterolaemia. Although bovine plasma apoB-100 is useful for diagnosis of fatty liver and related diseases in dairy cows [49-52], the clinical significance of bovine LDL-C is unknown. A decrease of apoB-100 also occurs in cows during the early lactation stage $[53,54]$, which is probably caused by hepatic TG accumulation. In this study, significant depletion of LDL-C was observed in cows at parturition and which not became pregnant. It is well established that the most important role of LDL is 
delivery of cholesterol to peripheral tissues via LDL receptors. Rudling and Peterson [55] clearly demonstrated that the tissue concentrations of LDLs receptors are highest in corpus luteum or adrenal cortex, and that plasma LDLs are closely related to tissue LDL receptors. On the other hand, it was reported that there was no difference in the ability of LDL-C and HDL-C to stimulate progesterone production by cultured bovine corpus luteum cells [56]. The clinical importance of bovine serum LDL-C for steroidogenesis remains unclear. However, explanation and validation require further targeted cohort investigation to find reasons for later resumption of ovarian activity as well as effect of biochemical on reproductive performance in buffaloes.

\section{CONCLUSION}

It was concluded that postpartum ovarian activity has positive effect on the uterine involution. Earlier resumption of ovarian cyclicity leads to decrease in day open and service per conception in buffaloes. There were differences in level of some metabolic constituents and steroids observed in pregnant and non-pregnant buffalo groups. The postpartum profile of these constituents may be a good predictor of fertility status of these animals.

\section{REFERENCES}

[1] El-Wishy, A.B. (2007) The postpartum buffalo: I. Endocrinological changes and uterine involution. Animal Reproduction Science, 97, 201-215. doi:10.1016/j.anireprosci.2006.03.004

[2] Butler, W.R. and Smith, R.D. (1989) Interrelationships between energy balance and postpartum reproductive function in dairy cattle. Journal of Dairy Science, 72, 767-783. doi:10.3168/jds.S0022-0302(89)79169-4

[3] Konigsson, K., Savoini, G., Govoni, N., Invernizzi, G., Prandi, A., Kindahl, H. and Veronesi, M.C. (2008) Energy balance, leptin, NEFA and IGF-I plasma concentrations and resumption of post partum ovarian activity in swedish red and white breed cows. Acta Veterinaria Scandinavica, 50, 3. doi:10.1186/1751-0147-50-3

[4] Bertics, S.J., Grummer, R.R., Cadomiga, V.C. and Stoddard, E.E. (1992) Effect of prepartum dry matter intake on liver triglyceride concentration and early lactation. Journal of Dairy Science, 75, 1914-1922. doi:10.3168/jds.S0022-0302(92)77951-X

[5] Reid, I.M. and Roberts, C.J. (1983) Subclinical fatty liver in dairy cows. Irish Veterinary Journal, 37, 104-110.

[6] Gerloff, B.J., Herdt, T.H. and Emery, R.S. (1986) Relationship of hepatic lipidosis to health and performance in dairy cattle. Journal of the American Veterinary Medical Association, 188, 845-850.

[7] Canfield, R.W. and Butler, W.R. (1990) Energy balance and pulsatile LH secretion in early postpartum dairy cattle. Domestic Animal Endocrinology, 7, 323-330.

\section{doi:10.1016/0739-7240(90)90038-2}

[8] Zurek, E., Foxcroft, G.R. and Kennelly, J.J. (1995) Metabolic status and interval to first ovulation in postpartum dairy cows. Journal of Dairy Science, 78, 1909-1920. doi:10.3168/jds.S0022-0302(95)76816-3

[9] Villa-Godoy, G.A., Hughes, T.L., Emery, R.S., Chapin, L.T. and Fogwell, R.L. (1988) Association between energy balance and luteal function in lactating dairy cows. Journal of Dairy Science, 71, 1063-1072. doi:10.3168/jds.S0022-0302(88)79653-8

[10] NRC (2001) Nutrient requirements of dairy cattle. 7th Edition, National Academies Press, Washington DC, 381.

[11] Edmonson, A.J., Lean, I.J., Weaver, L.D., Farver, T. and Webster, G. (1989) A body condition scoring chart for Holstein dairy cows. Journal of Dairy Research, 72, 6878. doi:10.3168/jds.S0022-0302(89)79081-0

[12] Kask, K., Kindahl, H. and Gustafsson, H. (2000) Resumption of uterine and ovarian functions following dexamethasone-induced parturition in dairy cows. Acta Veterinaria Baltica, 3, 11-21.

[13] Bekana, M., Ekman, T. and Kindahl, H. (1994) Ultrasonography of the bovine postpartum uterus with retained fetal membranes. Journal of Veterinary Medicine A, 41, 653-662. doi:10.1111/j.1439-0442.1994.tb00133.x

[14] Sheldon, I.M., Noakes, D.E., Rycroft, A.N. and Dobson, H. (2002) Effect of postpartum manual examination of the vagina on uterine bacterial contamination in cows. Veterinary Record, 151, 531-534. doi:10.1136/vr.151.18.531

[15] Friedewald, T.W., Levy, R.I. and Fredrickson, D.S. (1972) Estimation of concentration of low-density lipoprotein cholesterol without the use of the preparative ultracentrifuge. Clinical Chemistry, 18, 499.

[16] SPSS (2007) IBM SPSS statistics 19 core system, user's guide, version 16.0. Statistical Analysis System Institute, Inc., Chicago.

[17] de Vries, M.J. and Veerkamp, R.F. (2000) Energy balance of dairy cattle in relation to milk production variables and fertility. Journal of Dairy Science, 83, 62-69. doi:10.3168/jds.S0022-0302(00)74856-9

[18] Buckley, F., O'Sullivan, K., Mee, J.F., Evans, R.D. and Dillon, P. (2003) Relationships among milk yield, body condition, cow weight, and reproduction in spring-calving Holstein-Friesians. Journal of Dairy Science, 86, 23082319. doi:10.3168/jds.S0022-0302(03)73823-5

[19] Roche, J.R., Macdonald, K.A., Burke, C.R., Lee, J.M. and Berry, D.P. (2007) Associations among body condition score, body weight, and reproductive performance in seasonal-calving dairy cattle. Journal of Dairy Science, 90, 376-391. doi:10.3168/jds.S0022-0302(07)72639-5

[20] Heinonen, K., Ettala, E. and Alanko, M. (1988) Effect of postpartum live weight loss on reproductive functions in dairy cows. Acta Veterinaria Scandinavica, 29, 249-254.

[21] Raheja, K.L., Burnside, E.B. and Schaeffer, L.R. (1989) Relationship between fertility and production in Holstein dairy cattle in different lactations. Journal of Dairy Science, 72, 2670-2678. doi:10.3168/jds.S0022-0302(89)79408-X 
[22] Villa-Godoy, A., Hughs, T.L., Emery, R.S., Chapin, L.T. and Fogwell, R.L. (1990) Influence of energy balance and body condition on estrus and estrous cycles in Holstein heifers. Journal of Dairy Science, 73, 2759-2765. doi:10.3168/jds.S0022-0302(90)78961-8

[23] Butler, W.R., Everett, R.W. and Coppock, C.E. (1981) The relationships between energy balance, milk production and ovulation in postpartum Holstein cows. Journal of Animal Science, 53, 742-748.

[24] Hoekstra, J., Van der Lugt, A.W., Van der Werf, J.H.J. and Ouweltjes, W. (1994) Genetic and phenotypic parameters for milk production and fertility traits in upgraded dairy cattle. Livestock Production Science, 40, 225-232. doi:10.1016/0301-6226(94)90090-6

[25] Beam, S.W. and Butler, W.R. (1999) Energy balance effects on follicular development and first ovulation in postpartum cows. Journal of Reproduction and Fertility (Suppl.), 54, 411-424.

[26] Darwash, A.O., Lamming, G.E. and Woolliams, J.A. (1999) The potential for identifying heritable endocrine parameters associated with fertility in post-partum dairy cows. Journal of Animal Science, 68, 333-347.

[27] Royal, M.D., Darwash, A.O., Flint, A.P.F., Webb, R., Woolliams, J.A., and Lamming, G.E. (2000) Declining fertility in dairy cattle: Changes in traditional and endocrine parameters of fertility. Journal of Animal Science, 70, 487-501.

[28] Sheldon, I.M., Noakes, D.E., Rycroft, A.N. and Dobson, H. (2003) The effect of intrauterine administration of estradiol on postpartum uterine involution in cattle. Theriogenology, 59, 1357-1371. doi:10.1016/S0093-691X(02)01169-X

[29] Hussein, H.A. (2005) Ultrasonographic evaluation for the effect of postpartal ovarian activity and uterine involution on subsequent reproductive performance of dairy cows. Assiut Veterinary Medical Journal, 51, 262-272.

[30] Usmani, R.H. (1992) Effect of non-gravid uterine horn on the pattern of resumption of ovarian functions in postpartum Nili Ravi buffaloes. Buffalo Journal, 8, 265-270.

[31] Singh, N., Chauhan, F.S. and Singh, M. (1979) Postpartum ovarian activity and fertility in buffaloes. Indian Journal of Dairy Science, 32, 134-139.

[32] Ireland, J.J., Fogwell, R.L., Oxender, W.D., Ames, K. and Cowley, J.L. (1984) Production of estradiol by each ovary during the estrus cycle of cows. Journal of Animal Science, 59, 764-771.

[33] Bonnet, B.N., Martin, S.W. and Meek, A.H. (1993) Assocciations of clinical findings, bacteriological and histological results of endometrial biopsy with reproductive performance of post partum dairy cows. Preventive Veterinary Medicine, 15, 205-220. doi:10.1016/0167-5877(93)90114-9

[34] El-Fouly, M.A., Afifi, Y. and Kirrella, A.K. (1977) Service period length in a herd of experimental buffaloes. Egypt. Journal of Animal Production, 17, 63-73.

[35] El-Wishy, A.B. (1979) Reproductive performance of Iraqi buffaloes. I. Pattern of female reproduction. Beiträge zur tropischen Landwirtschaft und Veterinärmedizin, 17, 77-
83.

[36] Chaudhry, M.A., Ahmad, M. and Khan, N.U. (1987) Postpartum involution of the cervix and uterus in Nili-Ravi buffaloes. Buffalo Journal, 3, 87-92.

[37] Shah, R.G., Dhami, A.J., Kharadi, V.B., Desai, P.M. and Kavani, F.S. (2004) Hormonal profile in fertile and infertile postpartum Surti buffaloes. Buffalo Journal, 20, 2942.

[38] Shanks, R.D., Freeman, A.E. and Berger, P.J. (1979) Relationship of reproductive factors with interval and rate of conception. Journal of Dairy Science, 62, 74-84. doi:10.3168/jds.S0022-0302(79)83205-1

[39] Darwash, A.O., Lamming, G.E. and Woolliams, J.A. (1997) The phynotypic association between the interval to post partum ovulation and trantional measures of fertility in dairy cattle. Journal of Animal Science, 65, 9-16. doi:10.1017/S1357729800016234

[40] Smith, M.C. and Wallace, J.M. (1998) Influence of post partum ovulation on re-establishment of pregnancy in multiparous and primiparous dairy cattle. Reproduction, Fertlity and Development, 10, 207-216. doi:10.1071/R98012

[41] Usmani, R.H., Ullah, N. and Shah, S.K. (1985) A note on the effect of suckling stimulus on uterine involution, postpartum ovarian activity and fertility in Nili Ravi buffaloes. Journal of Animal Production, 41, 119-122. doi:10.1017/S000335610001761X

[42] Tiwari, S.R. and Pathak, M.M. (1995) Influence of suckling on postpartum reproductive performance of Surti buffaloes. Buffalo Journal, 11, 213-217.

[43] Usmani, R.H., Dailey, R.A. and Inskeep, E.K. (1990) Effects of limited suckling and varying prepartum nutrition on postpartum reproductive traits of milked buffaloes. Journal of Dairy Science, 73, 1564-1570. doi:10.3168/jds.S0022-0302(90)78826-1

[44] Takkar, O.P., Singh, N., Jagjit, K. and Chaudhary, K.C. (1999) Augmentation of postpartum reproductive efficiency by the use of GnRH in buffaloes. Indian Journal of Animal Reproduction, 20, 9-11.

[45] Ahmed, N., Chaudhary, R.A., Tahir, M. and Ashraf, M. (1982) Seasonal variations in the frequency of oestrus, conception and calving in buffaloes under Pakistani conditions. Proceeding of the 28th Pakistan Science Confarance, Multan, 58.

[46] Devraj, M. and Janakiraman, K. (1986) Postpartum performance of Surti buffaloes. Indian Journal of Animal Sciences, 56, 532-534.

[47] Bertoni, G., Lombardelli, R. and Orioli, F. (1999) Postpartum reproductive and metabolic behaviour of fertile and infertile dairy cows with different genetic merit. $A s$ sociazione Scientifica di Produzione Animale (ASPA), Piacenza, 21-24 June, 413-415.

[48] Khasatiya, C.T. (2005) Reproductive traits and metabolic profile in postpartum fertile and infertile surti buffaloes. Indian Veterinary Journal, 82, 637-641.

[49] Marcos, E., Mazur, A., Cardot, P. and Rayssiguier, Y. (1990) Serum apolipoprotein B and A-I and naturally occurring fatty liver in dairy cows. Lipids, 25, 575-577. 


\section{doi:10.1007/BF02537168}

[50] Oikawa, S., Katoh, N., Kawawa, F. and Ono, Y. (1995) Decreased serum apolipoprotein B-100 and A-I concentrations in cows with ketosis and left displacement of the abomasum. American Journal of Veterinary Research, 58, 121-125.

[51] Oikawa, S. and Katoh, N. (1997) Reduced concentrations of apolipoproteins B-100 and A-I in serum from cows with retained placenta. Canadian Journal of Veterinary Research, 61, 312-314.

[52] Oikawa, S. and Katoh, N. (2002) Decreases in serum apolipoprotein B-100 and A-I concentrations in cows with milk fever and downer cows. Canadian Journal of Veterinary Research, 66, 31-34.

[53] Marcos, E., Mazur, A., Cardot, P. and Rayssiguier, Y. (1990) The effect of pregnancy and lactation on serum lipid and apolipoprotein B and A-I. Journal of Animal Physiology and Animal Nutrition, 64, 133-138. doi:10.1111/j.1439-0396.1990.tb00214.x

[54] Yamamoto, O., Oikawa, S. and Katoh, N. (1995) Enzymelinked immunosorbent assay for serum apolipoprotein B100 , a major triglyceride-transport protein in dairy cows. American Journal of Veterinary Research, 56, 1413-1417.

[55] Rudling, M.J. and Peterson, C.O. (1985) A simple binding assay for the determination of low-density lipoprotein receptors in cell homogenates. Biochimica et Biophysica Acta, 833, 359-365. doi:10.1016/0005-2760(85)90091-8

[56] Carrol, D.J., Grummer, R.R. and Mao, F.C. (1992) Progesterone production by cultured luteal cells in the presence of bovine low- and high-density lipoproteins purified by heparin affinity chromatography. Journal of Animal Science, 70, 2516-2526. 